УДК 657.422.8:657.633

DOI: 10.15673/fie.v10i3.1065

\author{
Маркова Т.Д. \\ кандидат економічних наук, старший викладач \\ кафедра обліку та аудиту \\ E-mail: markova.tetiana17@gmail.com
}

\section{Стрепенюк М.M. магістрант} кафедра обліку та аудиту

E-mail: marina.strepenyuk@ukr.net

\author{
Головаченко Л.М. \\ асистент \\ кафедра обліку та аудиту \\ E-mail: ludaoia2012@gmail.com \\ Римар Г.А. \\ магістрант \\ кафредра обліку та аудиту \\ Одеська національна академія харчових технологій \\ вул. Канатна, 112, м. Одеса, Україна, 65039 \\ E-mail: anna1995@te.net.ua
}

\title{
ОСОБЛИВОСТІ ВНУТРІШНЬОГОСПОДАРСЬКОГО КОНТРОЛЮ РОЗРАХУНКІВ З ПОКУПЦЯМИ ТА РЕАЛІЗАЦІЇ ГОТОВОї ПРОДУКЦії
}

У статті розглядається сутність поняття «внутрішньогосподарський контроль», «система внутрішньогосподарського контролю», теоретичні та практичні особливості контролю готової продукції та розрахунків з покупцями та замовниками на підприємстві. На базі дослідження та узагальнення сформовано власні етапи внутрішньогосподарського контролю готової продукції. Пропонується перелік інформаційних джерел в системі внутрішньогосподарського контролю готової продукції та розрахунків 3 покупцями та замовниками. Обґрунтовано низку ймовірних порушень при здійснені внутрішньогосподарського контролю. Рекомендовано методичні прийоми для виявлення порушень під час внутрішньогосподарського контролю готової продукції та розрахунків з покупцями та замовниками.

Ключові слова: внутрішньогосподарський контроль, система внутрішньогосподарського контролю; контроль розрахунків з покупцями та замовниками, контроль готової продукції.

This work is licensed under a Creative Commons Attribution 4.0 International License http://creativecommons.org/licenses/by/4.0/

Постановка проблеми та її зв'язок з важливими науковими та практичними завданнями. На даному етапі функціонування ринкової економіки кожне підприємство повинно забезпечувати необхідний рівень фінансових ресурсів, завдяки яким воно мало б здатність утримувати своїх постійних ділових партнерів та найманих працівників, а також здійснювати свої функції перед державою. Для досягнення стабільності фінансового стану підприємство має завжди одержувати максимальний прибуток за мінімальних витрат, дотримуючись розрахунків комерційним шляхом. Ця умова відіграє важливу роль в оцінці фінансових результатів підприємства.

Відповідно, існує потреба у планомірному проведенні внутрішньогосподарського контролю на підприємстві, за допомогою якої можна визначити ймовірні порушення, помилки та відхилення від норм, що суттєво можуть викривити результати фінансової звітності. Саме керівництво несе відповідальність за функціонування належної системи контролю. Через це керівник підприємства повинен створити потужну систему внутрішнього контролю, здатну забезпечити об'єктивне відображення фінансового стану підприємства.

Зауважуємо, що внутрішньогосподарському контролю підлягають всі ділянки обліку підприємства.
У ході господарської діяльності підприємство реалізує матеріальні цінності та надає послуги. На цьому етапі виникає дебіторська заборгованість за розрахунками з покупцями та замовниками, яка займає основну долю оборотних активів підприємства.

Отже, з'являється необхідність у конкретній організації та визначення особливостей внутрішньогосподарського контролю не тільки розрахунків 3 покупцями та замовниками, а й контроль за реалізацією готової продукції.

Аналіз останніх публікацій по проблемі. 3 визначеної проблематики питання обговорюються як на науково-теоретичному рівні, так і на практиці. Важливі питання організації внутрішньогосподарської перевірки готової продукції та розрахунків з покупцями та замовниками розкрито в працях таких вітчизняних вчених, як Ф.Ф. Бутинця, Є.В. Калюги, В.Д. Андрєєва, В.О. Зотова, В.Ф. Максімової, К.І. Редченка, Л.В. Гуцаленко, О.В. Добровольської, В.С. Непочатової, Н.І. Дороша, М.М. Коцупатрого, Г.О. Москалюка, О.М. Волковицької, Г.В. Яворова та багато інших. Проте, перелік важливих питань особливостей внутрішньогосподарського контролю готової продукції та розрахунків з покупцями та замовниками залишаються не висвітлені та вимагають як теоретичної, так і практичної уваги та підтверджують значимість даного дослідження. 
Формування цілей дослідження. Мета роботи - розкриття змісту поняття «внутрішньогосподарський контроль» та розгляд особливостей внутрішньогосподарського контролю готової продукції та розрахунків з покупцями і замовниками, дослідження як теоретичних так і практичних аспектів організації внутрішньогосподарського контролю розрахунків з покупцями та замовниками за реалізацію готової продукції в сучасних умовах. Для реалізації визначеної мети необхідно вирішити наступні завдання:

- визначення сутності «внутрішньогосподарський контроль»;

- розкриття порядку та етапів проведення внутрішньогосподарського контролю готової продукції та розрахунків з покупцями та замовниками;

- аргументування джерел інформації в сис- темі внутрішньогосподарського контролю виробництва продукції, iï реалізації та розрахунків з покупцями та замовниками;

- розгляд ймовірних порушень та методичних прийомів при проведенні контролю готової продукції та розрахунків з покупцями та замовниками на підприємстві.

Виклад основних результатів та їх обгрунтування. Організація системи внутрішньогосподарського контролю готової продукції та розрахунків 3 покупцями та замовниками є одним з важливих процесів функціонування кожного підприємства. Зазначимо, що дефініція поняття «внутрішньогосподарський контроль» зустрічається як в науковоекономічній літературі, так i в нормативнозаконодавчій базі (табл. 1).

Таблиця 1

Визначення сутності поняття «внутрішньогосподарський контроль» різними джерелами*

\begin{tabular}{|c|c|c|}
\hline $\begin{array}{l}\text { № } \\
\text { 3/П }\end{array}$ & Джерело/автор & Визначення \\
\hline 1. & $\begin{array}{l}\text { МСА } 315 \text { «дентифікація та } \\
\text { оцінка ризиків суттєвих ви- } \\
\text { кривлень через розуміння } \\
\text { суб'єкта господарювання та } \\
\text { його середовища» [2] }\end{array}$ & $\begin{array}{l}\text { Внутрішньогосподарський контроль є процесом, який визначається і } \\
\text { на який впливають особи наділені вповноваженими управління та } \\
\text { найвищого управління, а також інший персонал, який надає обгрун- } \\
\text { товану впевненість щодо досягнення цілей суб'єкта господарювання } \\
\text { стосовно достовірності фінансової звітності, ефективності діяльності } \\
\text { та дотримання застосованих законів і нормативних актів. }\end{array}$ \\
\hline 2. & Ф.Ф. Бутинець [3] & $\begin{array}{l}\text { Внутрішньогосподарський контроль - це контроль здійснюваний } \\
\text { органами внутрішнього контролю (головним бухгалтером підприєм- } \\
\text { ства, ревізійною комісією тощо). }\end{array}$ \\
\hline 3. & Є.В. Калюга [4] & $\begin{array}{l}\text { Внутрішньогосподарський контроль - це система безупинного спо- } \\
\text { стереження за ефективністю використання активів і зобов'язань під- } \\
\text { приємства, законністю і доцільністю господарських операцій, збере- } \\
\text { женням грошових коштів і матеріальних цінностей. Внутрішньогос- } \\
\text { подарський контроль є складовою частиною ринкового механізму, } \\
\text { одним із прийомів перевірки виконання прийнятих рішень, найваж- } \\
\text { ливішою функцією управління економікою. }\end{array}$ \\
\hline 4. & М.М. Коцупатрий [5] & $\begin{array}{l}\text { Внутрішньогосподарський контроль є системою безупинного спо- } \\
\text { стереження за ефективністю використання майна суб’єкта, законніс- } \\
\text { тю і доцільністю господарських операцій і процесів, збереження } \\
\text { грошових коштів. }\end{array}$ \\
\hline 5. & H.I. Дорош [6] & $\begin{array}{l}\text { Внутрішньогосподарський контроль - це процес, розроблений з ме- } \\
\text { тою досягнення поставлених завдань підприємства; розпочинається } 3 \\
\text { верхівки підприємства - ради директорів та менеджерів, які створю- } \\
\text { ють і зміцнюють структуру і характер здійснюваних контрольних } \\
\text { заходів в організації; прямо чи опосередковано включає в себе всіх } \\
\text { працівників підприємства; стосується всіх видів діяльності підпри- } \\
\text { ємства, починаючи } з \text { функціональних ланок, таких як маркетинг та } \\
\text { операційні підрозділи, до взаємовідносин з іншими підприємствами. }\end{array}$ \\
\hline 6. & Г.В. Яворова [7] & $\begin{array}{l}\text { Внутрішньогосподарський контроль - це система безупинного спо- } \\
\text { стереження за ефективністю використання майна, господарюючого } \\
\text { суб’єкта, законністю та доцільністю господарських операцій і проце- } \\
\text { сів, збереженням грошових коштів і матеріальних цінностей. }\end{array}$ \\
\hline
\end{tabular}

Запорукою успіху кожного підприємства $\epsilon$ правильна організація ефективно діючої системи внутрішньогосподарського контролю на підприємстві.

Під системою внутрішньогосподарського контролю розуміють систему елементів, принципів та процедур контролю, які створені для функціонування підприємства і служать для реалізації його функцій.

Внутрішньогосподарський контроль - це незалежний контроль з боку власників, управлінського персоналу підприємства або особи, уповноваженої обов'язками та функціями перевіряючого 3 метою недопущення фактів порушення законності, нераціо- 
нального використання та перевитрат виробничих ресурсів, невиконання передбачених виробничогосподарських планів діяльності і розвитку підприємства.

3 одного боку, особливістю системи внутрі шньогосподарського контролю є розпізнавати ризики, а 3 іншого - через відповідні процедури і методи обмежити їх величину. Для того, щоб така система контролю не була слабкою і була систематизована виникає необхідність у використанні етапів внутрішньогосподарського контролю [8].

На думку автора В.С. Непочатової існує декілька етапів проведення внутрішньгосподарського контролю розрахунків 3 покупцями та замовниками (рис.1).

\begin{tabular}{c}
\hline Встановлення суб'єктів дебіторської заборгованості \\
$\qquad$ \\
\hline Контроль за виконанням договірних зобов' язань \\
\hline Аналіз динаміки та структури заборгованості \\
$\downarrow$ \\
\hline Класифікація заборгованості на дійсну, сумнівну, безнадійну \\
$\qquad$ \\
\hline Контроль за своєчасністю проведення інвентаризації \\
розрахнів \\
$\downarrow$ \\
\hline Перевірка правильності та достовірності кожної суми заборго- \\
ваності \\
$\downarrow$ \\
\hline Оцінка стану бухгалтерського обліку і звітності розрахунків 3 \\
покупцями та замовниками \\
\hline
\end{tabular}

Рис.1. Етапи проведення внутрішньогосподарського контролю розрахунків з покупцями та замовниками [9]

Контроль розрахунків з покупцями та замовниками починається 3 перевірки виконання зобов’язань за договорами з реалізації готової продук- ціï. Спираючись на це нами було сформовано власні етапи проведення внутрішньогосподарського контролю готової продукції (рис.2).

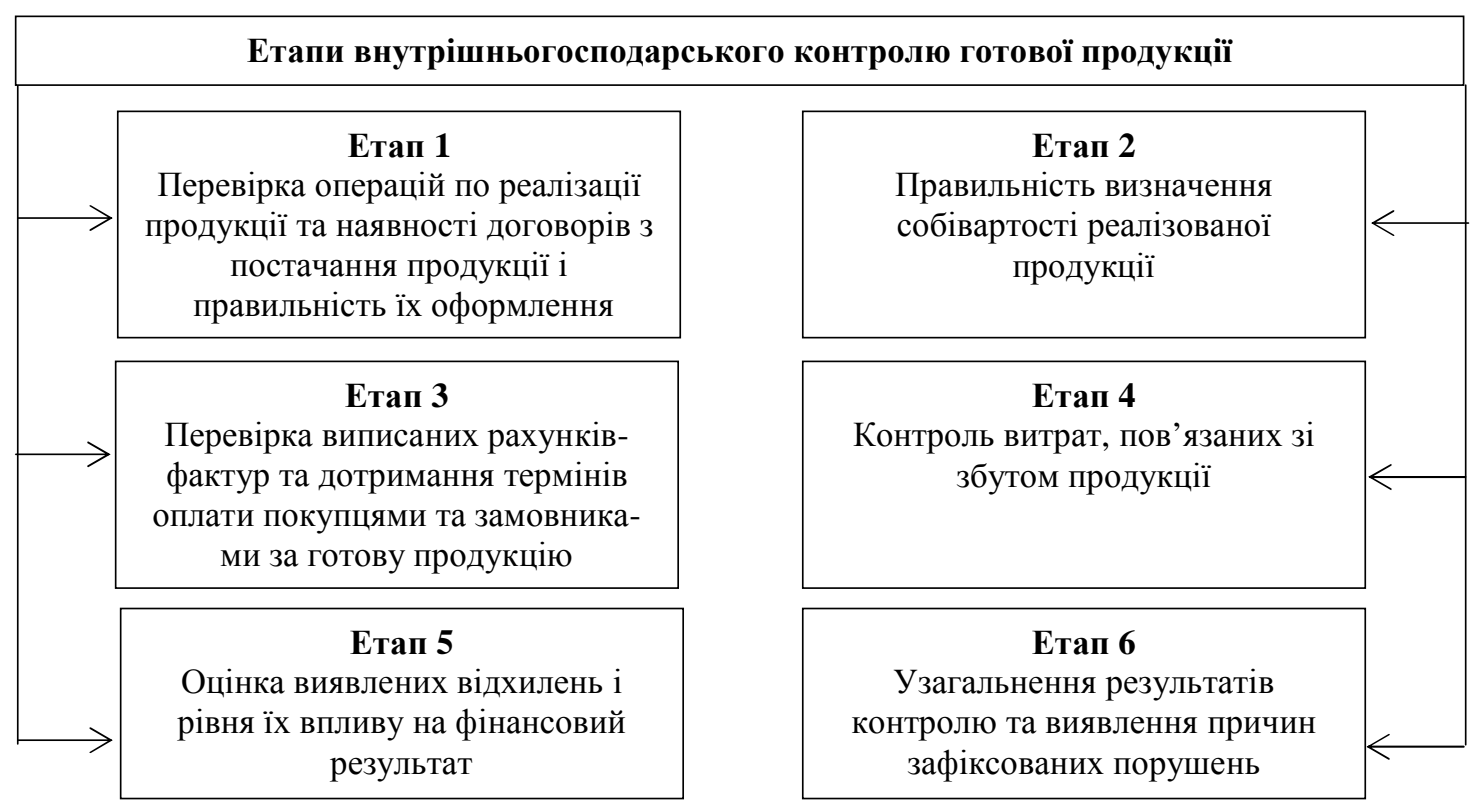

Рис.2. Етапи внутрішньогосподарського контролю готової продукції* * авторська розробка 
Ця послідовність дає змогу визначити перелік етапів внутрішньогосподарського контролю готової продукції.

Для кожної ділянки обліку існують свої джерела інформації внутрішньогосподарського контро- лю. Так, джерела інформації внутрішньогосподарського контролю готової продукції та розрахунків 3 покупцями та замовниками включають: первинну документацію, облікові регістри та звітність підприємства (табл.2 та табл.3).

Таблиця 2

Джерела інформації в діючій системі внутрішньогосподарського контролю розрахунків з покупцями та замовниками*

\begin{tabular}{|c|c|c|}
\hline $\begin{array}{l}\text { Джерело інформації } \\
\text { (документ) }\end{array}$ & $\begin{array}{c}\text { Нормативний акт, } \\
\text { що регулює порядок } \\
\text { оформлення документу }\end{array}$ & Зміст інформації \\
\hline \multicolumn{3}{|c|}{ Первинні документи } \\
\hline Договір & \multirow{6}{*}{$\begin{array}{l}\text { Закон України «Про } \\
\text { бухгалтерський облік та } \\
\text { фінансову звітність» }\end{array}$} & $\begin{array}{l}\text { Відображає домовленість сторін, спрямова- } \\
\text { ну на встановлення чи скасування } \\
\text { обов'язків та прав. }\end{array}$ \\
\hline Рахунок-фактура & & $\begin{array}{l}\text { Надається продавцем покупцеві і вміщує } \\
\text { перелік товарів, послуг робіт, їх кількість і } \\
\text { пропоновану ціну, по якій вони поставля- } \\
\text { ються покупцеві у разі його згоди, форма- } \\
\text { льні особливості товару (колір, вага і т. д.) }\end{array}$ \\
\hline Податкова накладна & & $\begin{array}{l}\text { Надає право платнику податку на включен- } \\
\text { ня відповідної суми до податкового креди- } \\
\text { ту. Податкова накладна виписується на ко- } \\
\text { жне повне або часткове постачання това- } \\
\text { рів/послуг. }\end{array}$ \\
\hline $\begin{array}{c}\text { Товарно-транспортна } \\
\text { накладна }\end{array}$ & & $\begin{array}{l}\text { Документ, необхідний для обліку, перемі- } \\
\text { щення, списання та оприбуткування товар- } \\
\text { но-матеріальних цінностей. }\end{array}$ \\
\hline Платіжне доручення & & $\begin{array}{l}\text { Являє собою доручення підприємства об- } \\
\text { слуговуючому його банку про перерахуван- } \\
\text { ня деякої суми зі свого рахунку на рахунок } \\
\text { іншого підприємства. }\end{array}$ \\
\hline Виписка банку & & $\begin{array}{l}\text { Видається банком підприємству і відобра- } \\
\text { жає грошовий рух на розрахунковому раху- } \\
\text { нку. }\end{array}$ \\
\hline \multicolumn{3}{|c|}{ Облікові регістри } \\
\hline Журнал №3 & \multirow{4}{*}{$\begin{array}{l}\text { Закон України «Про } \\
\text { бухгалтерський облік та } \\
\text { фінансову звітність» }\end{array}$} & $\begin{array}{l}\text { Містить відомості щодо дебіторської забор- } \\
\text { гованості за товари, роботи та послуги. }\end{array}$ \\
\hline $\begin{array}{l}\text { Відомості аналітичного обліку } \\
\text { розрахунків з покупцями } 3.1\end{array}$ & & $\begin{array}{l}\text { Відображений аналітичний облік } 3 \text { покуп- } \\
\text { цями та замовниками за рахунком } 36 \text {. }\end{array}$ \\
\hline $\begin{array}{l}\text { Відомості аналітичного обліку } \\
\text { розрахунків з дебіторами } 3.2\end{array}$ & & $\begin{array}{l}\text { Відображений аналітичний облік } 3 \text { дебіто- } \\
\text { рами за рахунком } 37 .\end{array}$ \\
\hline $\begin{array}{c}\text { Відомості аналітичного обліку } \\
\text { розрахунків за іншими операціями } \\
3.5\end{array}$ & & $\begin{array}{l}\text { Призначена для внутрішньогосподарських } \\
\text { розрахунків. Розрахунків за виданими аван- } \\
\text { сами, за авансами одержаними та іншими } \\
\text { операціями за рахунком } 68 \text {. }\end{array}$ \\
\hline \multicolumn{3}{|c|}{ Фінансова звітність підприємства } \\
\hline $\begin{array}{c}\text { Форма № } 1 \text { «Баланс (Звіт про фі- } \\
\text { нансовий стан)» }\end{array}$ & \multirow{3}{*}{$\begin{array}{l}\text { НП(С)БО } 1 \text { «Загальні } \\
\text { вимоги до фінансової } \\
\text { звітності» }\end{array}$} & $\begin{array}{l}\text { Дебіторська заборгованість за продукцію, } \\
\text { товари, роботи і послуги (рядок 1125) відо- } \\
\text { бражає заборгованість покупців за продук- } \\
\text { цію (товари), інші активи, здійснені роботи } \\
\text { та надані послуги. }\end{array}$ \\
\hline $\begin{array}{c}\text { Форма № } 3 \text { «Звіт про рух грошо- } \\
\text { вих коштів» }\end{array}$ & & $\begin{array}{l}\text { Відображаються одержані від покупців і } \\
\text { замовників аванси. }\end{array}$ \\
\hline $\begin{array}{c}\text { Форма № } 5 \text { «Примітки до річної } \\
\text { фінансової звітності» }\end{array}$ & & $\begin{array}{l}\text { Детально розшифровується інформація на- } \\
\text { ведена в Балансі. }\end{array}$ \\
\hline
\end{tabular}

* Складено авторами на підставі джерел $[1,10]$ 
Джерела інформації внутрішньогосподарського контролю готової продукції також місять документи на право здійснення підприємницької діяльності, а саме: документи про реєстрацію підприємства, установчі документи, ліцензії, свідоцтва про акредитацію, сертифікацію продукції, господарські угоди 3 покупцями та замовниками.

Таблиця 3

Джерела інформації в діючій системі внутрішньогосподарського контролю готової продукції*

\begin{tabular}{|c|c|c|}
\hline $\begin{array}{l}\text { Джерело інформації } \\
\text { (документ) }\end{array}$ & $\begin{array}{l}\text { Нормативний акт, що ре- } \\
\text { гулює порядок оформлен- } \\
\text { ня документу }\end{array}$ & Зміст інформації \\
\hline \multicolumn{3}{|c|}{ Первинні документи } \\
\hline Накладна & \multirow{3}{*}{$\begin{array}{l}\text { Закон України «Про } \\
\text { бухгалтерський облік та } \\
\text { фінансову звітність» }\end{array}$} & $\begin{array}{l}\text { Документ, що використовується при передачі товарно- } \\
\text { матеріальних цінностей від однієї особи іншій. }\end{array}$ \\
\hline $\begin{array}{l}\text { Приймально- } \\
\text { здавальні акти }\end{array}$ & & $\begin{array}{l}\text { Використовується замість приймально-здавальної наклад- } \\
\text { ної, при виготовленні складної і багатокомплектної проду- } \\
\text { кції. В ньому вказуються найменування, кількість, вартість } \\
\text { виробів, а також, що вироби повністю виготовлені, укомп- } \\
\text { лектовані та відповідають технічним умовам (умовам дого- } \\
\text { вору). }\end{array}$ \\
\hline $\begin{array}{l}\text { Приймально- } \\
\text { здавальна накладна }\end{array}$ & & $\begin{array}{l}\text { Використовується, коли передається продукція з цеху на } \\
\text { склад. У ній вказується номер цеху, що здав продукцію, } \\
\text { номер складу - отримувач, найменування виробів, номенк- } \\
\text { латурний номер, кількість зданих на склад виробів, обліко- } \\
\text { ва ціна і сума. }\end{array}$ \\
\hline Рахунок-фактура & & $\begin{array}{l}\text { Надається продавцем покупцеві і вміщує перелік товарів, } \\
\text { послуг робіт, їх кількість і пропоновану ціну, по якій вони } \\
\text { поставляються покупцеві у разі його згоди, формальні осо- } \\
\text { бливості товару, умови постачання і відомості про відправ- } \\
\text { ника і одержувача }\end{array}$ \\
\hline Акт про брак & & 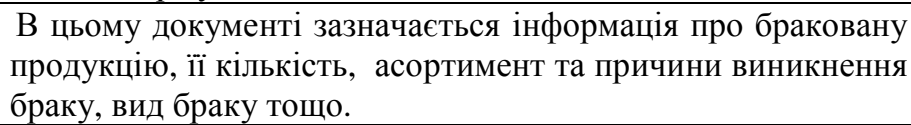 \\
\hline $\begin{array}{l}\text { Товарно-транспортна } \\
\text { накладна }\end{array}$ & & $\begin{array}{l}\text { Документ, необхідний для обліку, переміщення, списання } \\
\text { та оприбуткування товарно-матеріальних цінностей. }\end{array}$ \\
\hline & $B H$ & ирішні звіти \\
\hline $\begin{array}{l}\text { Звіт про залишки } \\
\text { готової продукції на } \\
\text { складі }\end{array}$ & & $\begin{array}{l}\text { Призначений для того, щоб знати скільки готової продукції } \\
\text { залишилося на складі. Цей звіт складається майже кожен } \\
\text { день. }\end{array}$ \\
\hline $\begin{array}{l}\text { Звіт про дебіторську } \\
\text { заборгованість }\end{array}$ & $\begin{array}{l}\text { Закон України «Про } \\
\text { бухгалтерський облік }\end{array}$ & $\begin{array}{l}\text { Документ, який містить інформацію про підписані угоди } \\
\text { про відстрочку платежів і непогашену заборгованість. Та- } \\
\text { кий звіт складають працівники фінансового відділу на підс- } \\
\text { таві зведень дебіторської заборгованості. щодня, щотижня, } \\
\text { щомісяця. }\end{array}$ \\
\hline $\begin{array}{l}\text { Звіт про наявність } \\
\text { простроченої дебі- } \\
\text { торської заборгова- } \\
\text { ності }\end{array}$ & та фінансову звітність» & $\begin{array}{l}\text { Ведеться для того, щоб знати, хто ще не сплатив гроші за } \\
\text { продукцію. Взяв, але не сплатив. }\end{array}$ \\
\hline $\begin{array}{l}\text { Звіт про виробництво } \\
\text { продукції }\end{array}$ & & $\begin{array}{l}\text { Цей звіт складається кожного дня. Для того, що знати скі- } \\
\text { льки продукції вироблено, скільки треба ще виготовити, чи } \\
\text { можна все її реалізувати. }\end{array}$ \\
\hline & & ументи ВГК \\
\hline $\begin{array}{l}\text { Акти інвентаризації } \\
\text { незавершеного виро- } \\
\text { бництва }\end{array}$ & $\begin{array}{l}\text { Закон України «Про } \\
\text { бухгалтерський облік та } \\
\text { фінансову звітність» }\end{array}$ & $\begin{array}{l}\text { Призначений для оформлення місячної і річної інвентари- } \\
\text { зації на складах і в цехах }\end{array}$ \\
\hline & Oб. & кові реєстри \\
\hline $\begin{array}{l}\text { Картки або книги } \\
\text { складського обліку }\end{array}$ & $\begin{array}{l}\text { Закон України «Про } \\
\text { бухгалтерський облік та } \\
\text { фінансову звітність» }\end{array}$ & $\begin{array}{l}\text { В цих облікових регістрах вказується облік готової продук- } \\
\text { ції на складі (кількість, види, назва, номенклатурний номер, } \\
\text { однини ця виміру, ціна). Також в них зазначається час над- } \\
\text { ходження і відпуску готової продукції, а також щодня роб- } \\
\text { ляться записи про ії залишки. }\end{array}$ \\
\hline
\end{tabular}


Продовження табл. 3

\begin{tabular}{|c|c|c|}
\hline $\begin{array}{l}\text { Джерело інформації } \\
\text { (документ) }\end{array}$ & $\begin{array}{c}\text { Нормативний акт, } \\
\text { що регулює порядок } \\
\text { оформлення документу }\end{array}$ & Зміст інформації \\
\hline Відомість & & $\begin{array}{l}\text { Складається в двох екземплярах після здачі оформлених } \\
\text { накладних. }\end{array}$ \\
\hline Оборотні відомості & & $\begin{array}{l}\text { Систематизують інформацію про дані синтетичних і ана- } \\
\text { літичних рахунків. }\end{array}$ \\
\hline Сальдові відомості & & $\begin{array}{l}\text { Ведуться за аналітичними рахунками товарно- } \\
\text { матеріальних цінностей } 3 \text { великою кількістю найменувань } \\
\text { (інструменти, найменування виробів і т.д.). }\end{array}$ \\
\hline \multicolumn{3}{|c|}{ Статистична звітність підприємства } \\
\hline $\begin{array}{l}\text { Форма 1П-НПП } \\
\text { «Звіт про випуск } \\
\text { продукції» }\end{array}$ & & $\begin{array}{l}\text { Відображаються дані щодо видів промислової } \\
\text { продукції, яку було вироблено за звітний рік на власних } \\
\text { або орендованих потужностях (з власної сировини або си- } \\
\text { ровини замовника). }\end{array}$ \\
\hline \multicolumn{3}{|c|}{ Фінансова звітність підприємства } \\
\hline $\begin{array}{l}\text { Форма № } 1 \ll \text { Баланс } \\
\text { (Звіт про фінансовий } \\
\text { стан)» }\end{array}$ & \multirow[t]{2}{*}{$\begin{array}{l}\text { Закон України «Про } \\
\text { бухгалтерський облік та } \\
\text { фінансову звітність» }\end{array}$} & $\begin{array}{l}\text { Готова продукція знаходиться у II розділі ,ст. 1103. Це до- } \\
\text { даткова стаття Балансу. Це запаси виробів на складі } \\
\text {,обробка яких закінчена та які пройшли випробуванн,, } \\
\text { приймання, укомплектовані згідно з умовами договорів } \\
\text { замовниками та відповідають технічним умовам і стандар- } \\
\text { там. }\end{array}$ \\
\hline $\begin{array}{l}\text { № } 3 \text { «Звіт про рух } \\
\text { грошових коштів» }\end{array}$ & & Надходження та витати грошових коштів \\
\hline
\end{tabular}

* Складено авторами на підставі джерел [1]

Під методом внутрішньогосподарського контролю слід розуміти сукупність методичних прийомів i способів, за допомогою яких можна систематизувати ряд численних порушень та зловживань стосовно відображення в обліку інформації про майно та зобов'язання підприємства.

На сьогоднішній день серед українських вчених немає узгодженого підходу щодо єдиної класифікації загальних методів внутрішньогосподарського контролю.

На думку М.Д. Ковінька існує шість типів методів внутрішньогосподарського контролю, такі як: розподіл обов'язків та відповідальності; система не- залежних перевірок; документальний контроль; розрахунково-аналітичні; узагальнення і реалізація результатів контролю; фізичні засоби контролю та охорони [11].

На вибір певного методу контролю впливає велика кількість факторів. Так, професор В.С. Рудницький серед них виділив найголовніші: наявність внутрішньофірмових стандартів, види діяльності підприємства, використання ЕОМ у контролі [12].

На нашу думку, для внутрішньогосподарського контролю розрахунків з покупцями та замовниками слід застосовувати два методичні прийоми (табл.4).

Таблиця 4

Методичні прийоми для виявлення порушень щодо розрахунків 3 покупцями та замовниками*

\begin{tabular}{|c|c|c|}
\hline & $\begin{array}{l}\text { Методичний } \\
\text { прийом }\end{array}$ & Порушення, які можуть бути виявлені \\
\hline \multirow{5}{*}{ 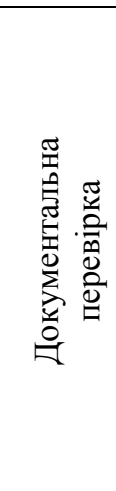 } & $\begin{array}{l}\text { Перевірка документів за формаль- } \\
\text { ними ознаками }\end{array}$ & $\begin{array}{l}\text { Неточне документів: рахунків-фактур, накладних, товарно- } \\
\text { транспортних накладних і т.п.; відсутність необхідних реквізи- } \\
\text { тів на документах; неправильне та несвоєчасне відображення } \\
\text { дат документів; невідповідність підписів суб'єктів, ким були } \\
\text { складені документи. }\end{array}$ \\
\hline & Перевірка документів за змістом & Незаконне за фіксування операцій в документах. \\
\hline & Арифметична перевірка & $\begin{array}{l}\text { Неправильні підрахунки залишків дебіторської заборгованості } \\
\text { за товари, роботи та послуги; приховання достовірних сум. }\end{array}$ \\
\hline & Зустрічна перевірка & $\begin{array}{l}\text { Наявність виправлень в документах та відображення господар- } \\
\text { ських операцій, що суперечать логіці. }\end{array}$ \\
\hline & $\begin{array}{l}\text { Оцінка законності й обгрунтова- } \\
\text { ності господарських операцій }\end{array}$ & $\begin{array}{l}\text { Не вірно та незаконно відображені господарські операції в до- } \\
\text { кументах, не правильно вказані суми. }\end{array}$ \\
\hline \multirow{2}{*}{ 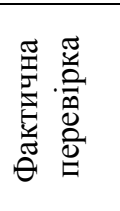 } & Інвентаризація & $\begin{array}{l}\text { Неправильно відображені суми в договорах, в рахунках- } \\
\text { фактурах, терміни виникнення заборгованості дебіторів. }\end{array}$ \\
\hline & $\begin{array}{l}\text { Отримання письмових пояснень та } \\
\text { довідок }\end{array}$ & $\begin{array}{l}\text { Не вірно оформлені довідки або неправильно дані пояснення } \\
\text { щодо виникнення питань за розрахунками з покупцями та за- } \\
\text { мовниками. }\end{array}$ \\
\hline
\end{tabular}


У процесі здійснення внутрішньогосподарського контролю готової продукції, як і розрахунків 3 покупцями та замовниками для одержання необхідних доказів також використовують два методичні прийоми: документальна та фактична перевірка (табл.
5). Але, суттєвою відмінністю є те, що для внутрішньогосподарського контролю готової продукції використовуються контрольні заміри та експертнолабораторний аналіз.

Таблиця 5

Методичні прийоми для виявлення порушень щодо реалізації продукції*

\begin{tabular}{|c|c|c|}
\hline & $\begin{array}{l}\text { Методичний } \\
\text { прийом }\end{array}$ & Порушення, які можуть бути виявлені \\
\hline \multirow{7}{*}{ 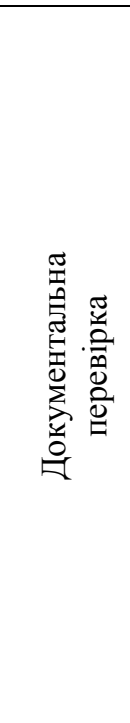 } & $\begin{array}{l}\text { Перевірка документів } \\
\text { за формальними ознаками }\end{array}$ & $\begin{array}{l}\text { Неточне документів: рахунків-фактур, накладних, товарно- } \\
\text { транспортних накладних і т.п.; відсутність необхідних рекві- } \\
\text { зитів на документах; неправильне та несвоєчасне відобра- } \\
\text { ження дат документів; невідповідність підписів осіб, якими } \\
\text { був складений документ. }\end{array}$ \\
\hline & Логічна перевірка документів & Не вірне відображення господарської операції в документі. \\
\hline & $\begin{array}{l}\text { Перевірка правильності відображення } \\
\text { господарських операцій з даних доку- } \\
\text { ментів у реєстрах бухгалтерського } \\
\text { обліку }\end{array}$ & $\begin{array}{l}\text { Неправильна кореспонденція рахунків, невідповідність сум у } \\
\text { документах бухгалтерського обліку, відсутність деяких запи- } \\
\text { сів по прикріплених документах призводять до виникнення } \\
\text { вагомих порушень. }\end{array}$ \\
\hline & Перевірка документів за змістом & Незаконне за фіксування операцій в документах. \\
\hline & Арифметична перевірка & $\begin{array}{l}\text { Неправильні підрахунки сум дебіторської заборгованості за } \\
\text { товари, роботи та послуги; приховання достовірних сум. }\end{array}$ \\
\hline & Зустрічна перевірка & $\begin{array}{l}\text { Наявність виправлень в документах та відображення госпо- } \\
\text { дарських операцій, що суперечать логіці. }\end{array}$ \\
\hline & $\begin{array}{l}\text { Оцінка законності й обгрунтованос- } \\
\text { ті господарських операцій }\end{array}$ & $\begin{array}{l}\text { Не вірно та незаконно відображені господарські операції в } \\
\text { документах, не правильно вказані суми. }\end{array}$ \\
\hline \multirow{2}{*}{ 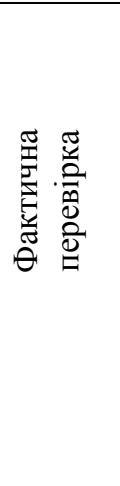 } & Інвентаризація & $\begin{array}{l}\text { Невідповідність повноти відображення виручки, одержаної від } \\
\text { покупців за реалізовану готову продукцію; неправильне визна- } \\
\text { чення фінансового результату від продажу продукції (співстав- } \\
\text { лення отриманих доходів та понесених протягом звітного періо- } \\
\text { ду витрат); неправильне нарахування та сплата податку на дода- } \\
\text { ну вартість (операції з відвантаження продукції). }\end{array}$ \\
\hline & Контрольні заміри & $\begin{array}{l}\text { Невідповідність характеру, кількості та вартості виконаних } \\
\text { робіт, вказаних в актах приймання; відповідність виконаних } \\
\text { робіт складу робіт, передбаченому нормами кошторисів, че- } \\
\text { рез які складено застосовані при розрахунках одиничні розці- } \\
\text { нки, калькуляції та прейскурантні ціни, а також розцінками в } \\
\text { нарядах. }\end{array}$ \\
\hline
\end{tabular}

* авторська розробка

Тому, здійснюючи внутрішньогосподарський контроль розрахунків з покупцями та замовниками, контролер має розуміти, що за правильно зовнішньо оформленими документами можуть бути приховані помилки та порушення, які погано позначаються на господарській діяльності підприємства (табл.6).

Отже, для того, щоб повністю виявити найнезначніші ознаки зловживань потрібно застосовувати комплекс методичних прийомів, які наведені вище.

Таблиця 6

Ймовірні порушення, виявлені за результатами контролю у розрахунках з покупцями та замовниками*

\begin{tabular}{|l|l|l|}
\hline \multicolumn{1}{|c|}{ Зміст порушення } & \multicolumn{1}{|c|}{$\begin{array}{c}\text { Нормативний акт, положення } \\
\text { якого порушено }\end{array}$} & \multicolumn{1}{|c|}{ Результати порушення } \\
\hline $\begin{array}{l}\text { 1. Неправильна класифікація дебі- } \\
\text { торської заборгованості }\end{array}$ & $\begin{array}{l}\text { П(С)БО 10 «Дебіторська заборгова- } \\
\text { ність» }\end{array}$ & $\begin{array}{l}\text { Викривлюються показники фінансової } \\
\text { звітності }\end{array}$ \\
\hline $\begin{array}{l}\text { 2. Відсутність первинних докумен- } \\
\text { тів або неналежне їх оформлення } \\
\text { облік та фінансову звітність», ПКУ, } \\
\text { Положення «Про документальне } \\
\text { забезпечення записів в бухгалтерсь- } \\
\text { кому обліку» }\end{array}$ & $\begin{array}{l}\text { певірно складена фінансова звітність } \\
\text { денн бухгалтерського та фінансового } \\
\text { обліку }\end{array}$ \\
\hline
\end{tabular}


Продовження табл.6

\begin{tabular}{|c|c|c|}
\hline Зміст порушення & $\begin{array}{c}\text { Нормативний акт, положення } \\
\text { якого порушено }\end{array}$ & Результати порушення \\
\hline $\begin{array}{l}\text { 3. Погашення дебіторської заборго- } \\
\text { ваності покупців, а саме розрахунків } \\
3 \text { готівкою із можливим не оприбут- } \\
\text { куванням в касу та списання такої } \\
\text { заборгованості на безнадійну (шах- } \\
\text { райство) }\end{array}$ & $\begin{array}{l}\text { П(С)БО } 10 \text { «Дебіторська заборгова- } \\
\text { ність» }\end{array}$ & $\begin{array}{l}\text { Списана з Балансу безнадійна забор- } \\
\text { гованість автоматично потрапляє до } \\
\text { інших операційних витрат. Різн- } \\
\text { ця,яка виникає, якщо недостатньо } \\
\text { резерву сумнівних боргів списується } \\
\text { на витрати періоду. }\end{array}$ \\
\hline $\begin{array}{l}\text { 4. Невідповідність методики нараху- } \\
\text { вання резерву сумнівних боргів } 3 \\
\text { методикою, визначеною Наказом про } \\
\text { облікову політику }\end{array}$ & $\begin{array}{l}\text { П(С)БО } 10 \text { «Дебіторська заборгова- } \\
\text { ність» }\end{array}$ & $\begin{array}{l}\text { Як, результат неправильне ведення } \\
\text { бухгалтерського обліку та фінансової } \\
\text { звітності }\end{array}$ \\
\hline $\begin{array}{l}\text { 5. Неправильне відображання коре- } \\
\text { спонденції рахунків бухгалтерсько- } \\
\text { го обліку }(361,362)\end{array}$ & $\begin{array}{l}\text { Закон України «Про бухгалтерський } \\
\text { облік та фінансову звітність» }\end{array}$ & $\begin{array}{l}\text { Результатом такого порушення } є \text { не- } \\
\text { правильне ведення бухгалтерського } \\
\text { обліку та фінансової звітності }\end{array}$ \\
\hline $\begin{array}{l}\text { 6. Не вірне відображення за стаття- } \\
\text { ми Балансу залишків заборгованості } \\
\text { або перекручування залишків дебі- } \\
\text { торської заборгованості }\end{array}$ & $\begin{array}{l}\text { НП(С)БО } 1 \text { «Загальні вимоги до фі- } \\
\text { нансової звітності», Положення «Про } \\
\text { документальне забезпечення записів } \\
\text { в бухгалтерському обліку» }\end{array}$ & $\begin{array}{l}\text { Завищення залишків дебіторської за- } \\
\text { боргованості може привести, навіть до } \\
\text { банкрутства підприємства. }\end{array}$ \\
\hline $\begin{array}{l}\text { 7.Відсутність звірок взаємних роз- } \\
\text { рахунків }\end{array}$ & $\begin{array}{l}\text { Положення про інвентаризацію акти- } \\
\text { вів та зобов'язань }\end{array}$ & $\begin{array}{l}\text { Наявність фальсифікацій, перекру- } \\
\text { чення. }\end{array}$ \\
\hline
\end{tabular}

* Складено авторами на підставі джерел $[1,10,13,14,15,16]$

Під час проведення контролю з випуску та шення, наведені в табл.7. реалізації продукції контролер може виявити пору-

Таблиця 7

Ймовірні порушення, виявлені за результатами контролю готової продукції*

\begin{tabular}{|c|c|c|}
\hline Зміст порушення & $\begin{array}{c}\text { Нормативний акт, положення } \\
\text { якого порушено }\end{array}$ & Результати порушення \\
\hline Нестача готової продукції & $\begin{array}{l}\text { Положення про інвентаризацію } \\
\text { активів та зобов’ язань }\end{array}$ & $\begin{array}{l}\text { Може призвести до перебоїв у процесі вироб- } \\
\text { ництва, до недовантаження виробничої потуж- } \\
\text { ності, падіння обсягів випуску продукції, зрос- } \\
\text { тання собівартості, до збитків }\end{array}$ \\
\hline $\begin{array}{l}\text { Завищення собівартості } \\
\text { готової продукції }\end{array}$ & П(С)БО 16 «Витрати» & $\begin{array}{l}\text { Призводить до невиправданого завищення } \\
\text { прибутку або навпаки }\end{array}$ \\
\hline $\begin{array}{l}\text { Заниження доходу від реа- } \\
\text { лізації }\end{array}$ & П(С)БО 15 «Доходи» & Крадіжка \\
\hline $\begin{array}{l}\text { Наявність непідтвердженої } \\
\text { дебіторської заборгованості }\end{array}$ & $\begin{array}{l}\text { Положення про інвентаризацію } \\
\text { активів та зобов' язань }\end{array}$ & Викривлення фінансової звітності \\
\hline $\begin{array}{l}\text { Завищення вартості незаве- } \\
\text { ршеного виробництва }\end{array}$ & $\begin{array}{l}\text { Закон України «Про бухгал- } \\
\text { терський облік та фінансову } \\
\text { звітність в Україні» }\end{array}$ & $\begin{array}{l}\text { Призводить до завищення собівартості проду- } \\
\text { кції }\end{array}$ \\
\hline
\end{tabular}

* Складено авторами на підставі джерел $[1,16,17,18]$

Виходячи $з$ вище сказаного можна зробити висновок, що перераховані порушення суттєво впливають на фінансовий результат діяльності підприємства та на оформлення і ведення бухгалтерського обліку та фінансової звітності.

Висновки та перспективи подалыших досліджень.

Проведені дослідження підтверджують важливість розуміння сутності категорії «внутрішньогосподарський контроль», оскільки він займає вагоме місце в господарській діяльності підприємства. В результаті проведеного дослідження ми визначили, що «внутрішньогосподарський контроль» - це систематизована категорія спостереження, яка спрямована на досягнення ефективного використання майна підприємства, законності відображення господарських операцій і правильності управління грошовими потоками.

В результаті узагальненого вивчення процесу внутрішньогосподарського контролю на підприємствах, зокрема таких ділянок, як розрахунки з покупцями і замовниками та реалізації готової продукції, особливості полягають, на нашу думку, у наступному:

1. Правильне визначення призначення внутрішньогосподарського контролю на підприємстві, враховуючи, що ці ділянки є досить вагомо важливі, оскільки розрахунки з покупцями та замовниками це наша дебіторська заборгованість, мета якої є бути 
своєчасно погашена. А, реалізація готової продукції це наш дохід (виручка), від якого залежить безупинне виробництво та фінансово-господарська діяльність.

2. Правильне визначення порядку та етапи проведення внутрішньогосподарського контролю розрахунків з покупцями і замовниками та реалізації готової продукції для уникнення ймовірних порушень ведення бухгалтерсько-фінансового обліку та аналітичного забезпечення потрібної інформації для прийняття управлінських рішень щодо ефективного розвитку діяльності підприємств.

Дослідження показують, що велику кількість ймовірних порушень та зловживань на підприємстві можна виявити за допомогою методичних прийомів внутрішньогосподарського контролю. А правильно організована система внутрішньогосподарського контролю є запорукою успішного розвитку та удосконалення підприємства в перспективі.

В умовах сьогодення потреба в здійсненні внутрішньогосподарського контролю готової продукції та розрахунків 3 покупцями та замовниками зростає.

Це зумовлено тим, саме випуск готової продукції та їі реалізація є одними із головних процесів діяльності підприємства, що суттєво впливають на фінансову звітність, а в подальшому і на фінансовий результат.

\section{Література}

1. Про бухгалтерський облік і фінансову звітність в Україні: Закон України від 16.07.99 р. № 996-XIV за станом на 01.07.2018 р. Верховна Рада України. Київ. URL: http://zakon.rada.gov.ua/laws/show/996-14 (дата 3вернення: 12.08.2018)

2. Міжнародний стандарт аудиту 315: URL:http/ /www/apu.com.uа (дата звернення: 15.08.2018)

3. Аудит і ревізія підприємницької діяльності: навч. посібн. для студ. вузів спец. 7.050106 «Облік і аудит» / Бутинець Ф.Ф. та ін. Житомир: ПП «Рута», 2001. 416 с.

4. Калюга Є.В. Фінансово-господарський контроль у системі управління. К.: Ельга, Ніка-Центр, 2002. $360 \mathrm{c}$.

5. Коцупатрий М. Внутрішньогосподарський контроль: організаційні аспекти та класифікаційні ознаки // Економічний аналіз. 2010. № 6. С. 433-436.

6. Дорош Н.І. Внутрішній контроль та аудит в управлінні ризиками на підприємстві // Вісник Львівської комерційної академії. Серія: Економічна. 2014. Вип. 44. С. 148-152.

7. Яворова Г.В. Обумовленість виникнення та сучасний стан внутрішньогосподарського контролю на підприємствах України // Інноваційна економіка. 2012. №11. С. 274-276.

8. Бутинець Т.А. Система внутрішнього контролю фірми // Економічні науки. Сер.: Облік і фінанси. 2010. Вип. 7(25). С. 234-245.

9. Непочатова В.С. Внутрішній контроль розрахунків з покупцями та замовниками // Молодий вчений. 2016. №3. C. 134-138.

10. Загальні вимоги до фінансової звітності: Національне положення (стандарт) бухгалтерського обліку 1: затв. наказом Мінфіну від 07.02.2013 №73 за станом на 03.08.2018 p. URL: http://zakon.rada.gov.ua/laws/show/z0336-13 (дата звернення: 11.08.2018).

11.Ковінько М.Д. Внутрішній контроль господарської діяльності підприємства: навч. посіб. для студ. вищ. навч. закл. Фастів: Поліфаст, 2006. 440 с.

12. Рудницький В.С. Методологія і організація аудиту. Тернопіль: Економічна думка, 1998. 192 с.

13. Дебіторська заборгованість: Положення (стандарт) бухгалтерського обліку 10: затв. наказом Мінфіну від 08.10.99 р. № 237 за станом на 09.08.2013 p. URL: http://zakon.rada.gov.ua/laws/show/z0725-99 (дата звернення: 11.08.2018).

14.Податковий кодекс України від 02.12.2010 року № 2755-VI за станом на 01.01.2018 p. URL: http://zakon.rada.gov.ua/laws/main/2755-17 (дата звернення: 11.08.2018).

15.Про документальне забезпечення записів у бухгалтерському обліку: Положення затв. наказом Мінфіну від 24.05.95 р. № 88 за станом на 03.08.2018 p. URL: http://zakon.rada.gov.ua/laws/show/z0168-95 (дата звернення: 11.08.2018).

16.Положення про інвентаризацію активів та зобов’язань: затв. наказом Мінфіну від 02.09.2014 р. №879 за станом на 18.11.2016 p. URL: http://zakon.rada.gov.ua/laws/show/z1365-14 (дата звернення: 10.08.2018).

17. Витрати: Положення (стандарт) бухгалтерського обліку 16: затв. наказом Мінфіну від 31.12 .99 р. № 318 за станом на 09.08.2013 p. URL:http://zakon.rada.gov.ua/laws/show/z0027-00 (дата звернення: 11.08.2018).

18. Доходи: Положення (стандарт) бухгалтерського обліку 15: затв. наказом Мінфіну від 22.11 .99 р. № 290 за станом на 09.08.2013 p. URL: http://zakon.rada.gov.ua/laws/show/z0860-99 (дата звернення: 09.08.2018). 
Маркова Т.Д.

кандидат экономических наук, старший преподаватель кафедра учета и аудита

E-mail: markova.tetiana17@gmail.com

Стрепенюк М.Н. магистрант кафредра учета и аудита

E-mail: marina.strepenyuk@ukr.net
Головаченко Л.М. ассистент

кафедра учета и аудита

E-mail: ludaoia2012@gmail.com

Рымарь A.A.

магистрант

кафедра учета и аудита

Одесская национальная академия пищевых технологий ул. Канатная, 112, г. Одесса, Украина, 65039

E-mail: anna1995@te.net.ua

\section{ОСОБЕННОСТИ ВНУТРЕННЕГО КОНТРОЛЯ РАСЧЕТОВ С ПОКУПАТЕЛЯМИ И РЕАЛИЗАЦИИ ГОТОВОЙ ПРОДУКЦИИ}

В статье рассматривается сущность понятия «внутрихозяйственный контроль», «система внутреннего контроля», теоретические и практические особенности контроля готовой продукции и расчетов с покупателями и заказчиками на предприятии. В результате проведенного исследования было установлено, что «внутрихозяйственный контроль» - это систематизированная категория наблюдения, которая направлена на достижение эфффективного использования имущества предприятия, законности отражения хозяйственных операций и правильности управления денежными потоками. Контроль расчетов с покупателями и заказчиками начинается с проверки выполнения обязательств по договорам по реализации готовой продукции. Таким образом, на базе исследования и обобщения сформированы собственные этапы проведения внутреннего контроля готовой продукции.

Для каждого участка учета существуют свои источники информации внутрихозяйственного контроля. Так, источники информации внутрихозяйственного контроля готовой продукции и расчетов с покупателями и заказчиками включают: первичную документацию, учетные регистры и отчетность предприятия. Предлагается перечень информационных источников в системе внутреннего контроля готовой продукции и расчетов с покупателями и заказчиками. Обосновано ряд вероятных нарушений при осуществлении внутреннего контроля.

Рекомендовано методические приемы для выявления нарушений во время внутреннего контроля готовой продукции и расчетов с покупателями и заказчиками. Исследования показывают, что большое количество вероятных нарушений и злоупотреблений на предприятии можно выявить с помощью методических приемов внутрихозяйственного контроля. А правильно организованная система внутреннего контроля является залогом успешного развития и совершенствования предприятия в перспективе. В современных условиях потребность в осуществлении внутрихозяйственного контроля готовой продукции и расчетов с покупателями и заказчиками растет. Это обусловлено тем, именно выпуск готовой продукции, и ее реализация является одним из главных процессов деятельности предприятия, которые существенно влияют на фринансовую отчетность, а в дальнейшем и на фринансовый результат.

Ключевые слова: внутрихозяйственный контроль, система внутреннего контроля; контроль расчетов с покупателями и заказчиками, контроль готовой продукции.

Markova T.

Ph. D., Assistant

Department of Accounting and Auditing

E-mail: markova.tetiana17@gmail.com

Strepenyuk M.

Undergraduate

Department of Accounting and Auditing

E-mail: marina.strepenyuk@ukr.net
Holovachenko L.

Assistant

Department of Accounting and Auditing

E-mail: ludaoia2012@gmail.com

Rymar H.

Undergraduate

Department of Accounting and Auditing

Odessa National Academy of Food Technologies

Kanatna str., 112, Odesa, Ukraine, 65039

E-mail: anna1995@te.net.ua

\section{FEATURES OF INTERNAL MONITORING OF PAYMENTS WITH BUYERS AND REALIZATION OF FINISHED PRODUCTS}

The essence of the notion of "intraeconomic control", "internal control system", theoretical and practical features of control of finished products and settlements with buyers and customers at the enterprise has been considered in the article. As a result of the conducted research, it was established that "on-farm control" is a systematized category of surveillance aimed at achieving effective use of the enterprise's property, the legality of reflecting economic operations and the correct management of cash flows. The control of settlements with buyers and customers begins with a verification of the fulfillment of obligations under contracts 
for the sale of finished products. Thus, on the basis of research and generalization, our own stages of internal control of finished products have been formed.

There are sources of in-house control information for each site. So, the sources of information of on-farm control of finished goods and settlements with buyers and customers include: primary documentation, accounting registers and enterprise reporting. The list of information sources in the system of internal control of finished goods and settlements with buyers and customers has been suggested. A number of possible violations in the implementation of internal control has been substantiated.

Some methodical methods for identifying violations during internal control of finished products and settlements with buyers and customers have been recommended. Studies show that a large number of possible violations and abuses at the enterprise can be detected using methodical methods of on-farm control. A properly organized system of internal control is the key to successful development and improvement of the enterprise in the future. In modern conditions, the need for implementation of on-farm control of finished products and settlements with buyers and customers is growing. This is due to the fact that the output of finished products, and its implementation is one of the main processes of the enterprise, activity which significantly affects the financial statements, and later the financial result.

Keywords: intraeconomic control, internal control system; control of settlements with buyers and customers, control of finished products.

\section{References}

1. Pro bukhhalterskyi oblik i finansovu zvitnist v Ukraini: Zakon Ukrainy vid 16.07.99 r. № 996-XIV: Za stanom na 01.07.2018 r. Verkhovna Rada Ukrainy. (2018). Retrieved August 12, 2018, from http://zakon.rada.gov.ua/laws/show/996-14

2. Mizhnarodnyi standart audytu 315. Retrieved August 15, 2018, from http//www/apu.com.ua

3. Butynets, F. F. (2001). Audyt i reviziia pidpryiemnytskoi diialnosti. Zhytomyr: PP «Ruta».

4. Kaliuha, Ye. V. (2002). Finansovo-hospodarskyi kontrol u systemi upravlinnia. Kyiv: Elha, Nika-Tsentr.

5. Kotsupatryi, M. (2010). Vnutrishnohospodarskyi kontrol: Orhanizatsiini aspekty ta klasyfikatsiini oznaky. Ekonomichnyi Analiz, (6), 433-436.

6. Dorosh, N. I. (2014). Vnutrishnii kontrol ta audyt v upravlinni ryzykamy na pidpryiemstvi. Visnyk Lvivskoi Komertsiinoi Akademii, (44), ekonomichna, 148-152.

7. Yavorova, H. V. (2012). Obumovlenist vynyknennia ta suchasnyi stan vnutrishnohospodarskoho kontroliu na pidpryiemstvakh Ukrainy. Innovatsiina Ekonomika, (11), 274-276. 234-245.

8. Butynets, T. A. (2010). Systema vnutrishnoho kontroliu firmy. Ekonomichni Nauky, (7 (25)), oblik i finansy,

9. Nepochatova, V. S. (2016). Vnutrishnii kontrol rozrakhunkiv z pokuptsiamy ta zamovnykamy. Molodyi Vchenyi, (3), 134-138.

10. Natsionalne polozhennia (standart) bukhhalterskoho obliku 1 «Zahalni vymohy do finansovoi zvitnosti» vid 07.02.2013 №73: Za stanom na 03.08.2018 r. (2018). Retrieved August 11, 2018, from http://zakon.rada.gov.ua/laws/show/z0336-13

11. Kovinko, M. D. (2006). Vnutrishnii kontrol hospodarskoi diialnosti pidpryiemstva. Fastiv: Polifast.

12. Rudnytskyi, V. S. (1998). Metodolohiia i orhanizatsiia audytu. Ternopil: Ekonomichna dumka.

13. Polozhennia (standart) bukhhalterskoho obliku 10 «Debitorska zabor-hovanist» vid 08.10.99 r. № 237: Za stanom na 09.08.2013 r. (2013). Retrieved August 11, 2018, from http://zakon.rada.gov.ua/laws/show/z0725-99

14. Podatkovyi kodeks Ukrainy vid 02.12.2010 roku № 2755-VI: Za stanom na 01.01.2018 r. (2018). Retrieved August 11, 2018, from http://zakon.rada.gov.ua/laws/main/2755-17

15. Pro dokumentalne zabezpechennia zapysiv u bukhhalterskomu obliku: Polozhennia zatverdzhene nakazom Minfinu vid 24.05.95 r. № 88: Za stanom na 03.08.2018 r. (2018). Retrieved August 11, 2018, from http://zakon.rada.gov.ua/laws/show/z0168-95

16. Polozhennia pro inventaryzatsiiu aktyviv ta zobov'iazan, zatverdzhene nakazom Ministerstva finansiv vid 02.09.2014 r. №879: $\mathrm{Za}$ stanom na 18.11.2016 r. (2016). Retrieved August 10, 2018, from http://zakon.rada.gov.ua/laws/show/z1365-14

17. Polozhennia (standart) bukhhalterskoho obliku 16 «Vytraty», zatverdzhene nakazom Ministerstva finansiv vid 31.12.99 r. № 318: Za stanom na 09.08.2013 r. (2013). Retrieved August 11, 2018, from http://zakon.rada.gov.ua/laws/show/z0027-00

18. Polozhennia (standart) bukhhalterskoho obliku 15 «Dokhody», zatverdzhene nakazom Ministerstva finansiv vid 22.11.99 r. № 290: Za stanom na 09.08.2013 r. (2013). Retrieved August 09, 2018, from http://zakon.rada.gov.ua/laws/show/z0860-99

Received 15 August 2018

Approved 30 August 2018

Available in Internet 17.10.2018

Цитування згідно ДСТУ 8302:2015

Маркова Т.Д., Головаченко Л.М., Стрепенюк М.М., Римар Г.А. Особливості внутрішньогосподарського контролю розрахунків з покупцями та реалізації готової продукції // Економіка харчової промисловості. 2018. Т. 10, Вип. 3. С. 83-93; doi: $10.15673 /$ fie.v10i3.1065

Cite as APA style citation

Markova, T., Holovachenko, L., Strepenyuk, M., \& Rymar, H. (2018). Features of internal monitoring of payments with buyers and realization of finished products. Food Industry Economics, 10(3), 83-93; doi: 10.15673/fie.v10i3.1065 